\title{
Peramalan Kebutuhan Manajemen Logistik Pada Usaha Depot Air Minum Isi Ulang Al-Fitrah
}

\author{
Henny Yulius ${ }^{1}$, Islami Yetti ${ }^{2}$ \\ Universitas Putra Indonesia 'YPTK' Padang \\ henny_yulius27@yahoo.com
}

http://dx.doi.org/10.22202/iei.2014.v1i1.1430

\begin{abstract}
ABSTRAK
Dengan adanya temuan baru beberapa tahun yang lalu tentang teknologi penyaringan air bersih (air isi ulang) dengan investasi yang cukup murah dan dapat dijadikan sebagai home industri (usaha mikro) dilokasi-lokasi permukiman. Harga jual produk otomatis sangat murah dibandingkan produk yang bermerek. Dan diperkirakan permintaan akan produk air isi ulang akan terus meningkat sejalan dengan perkembangan pengetahuan masyarakat tentang pentingnya air bersih untuk metabilosme sel-sel tubuh. Disamping itu pemerintah sangat mendukung dengan adanya usaha ini "Masyarakat dapat hidup sehat dengan biaya hidup ekonomi rendah".Peramalan adalah seni dan ilmu untuk memperkirakan kejadian dimasa depan.Peramalan suatu produk diharuskan menggunakan data produksi terdahulu. Peramalan untuk usaha depot air minum ini dilakukan selama 12 periode atau satu tahun. Perhitungan peramalan dilakukan dengan menggunakan software POM-QM. Metode yang digunakan ada 5, yaitu metode $M A$ (Moving Average), Moving Double Average, Weighted Moving Average, Exponensial Smoothing, Linear regretion. Dari kelima metode di atas, metode yang terbaik adalah metode linear regretion. Hasil yang ditunjukkan dalam grafik dengan metode regresi linier, yaitu bersifat linier dimana data peramalan untuk bulan ke 1 sampai ke bulan yang 12 merata atau linier dengan data peramalan sebelumnya (data aktual). Hal ini menyatakan bahwa peramalan dilakukan selama 12 bulan penuh. Grafik untuk peramalan regresi linier di bulan tertentu bersifat merata sehingga menunjukkan bahwa ramalan tidak jauh dari permintaan 12 bulan lalu (data aktual). Peramalan untuk metode regresi linier dimana permintaan sebanyak 15946 unit, dengan persentase peramalan sebesar, yaitu $0,02 \%$ dan standar error 533,61. Hal ini dalam suatu peramalan dapat dikatakan metode yang terbaik, yaitu jika memiliki persentase dan standar error yang lebih kecil, maka metode yang terpilih adalah metode regresi linier. Peramalan untuk usaha depot air minum ini dimana metode yang terpilih adalah regresi linier, karena regresi linier merupakan peramalan yang dilakukan selama 12 bulan penuh. Perbandingan dengan metode lain pun dimana peramalan hanya dilakukan di bulan tertentu atau bulan yang sudah ditentukan dalam peramalan sehingga dalam keakuratannya untuk metode regresi linier cukup baik, yaitu bernilai 0,02\% dengan standar error 533,61.
\end{abstract}

Kata Kunci: peramalan, air isi ulang, deret berkala

\section{PENDAHULUAN}

Air merupakan sumber daya alam yang memegang peranan penting di dalam kehidupan umat manusia. Air merupakan kebutuhan dasar bagi kehidupan sehari-hari, bagai sumber kehidupan itu sendiri. Pemakaiannya sekarang terus meningkat untuk memenuhi kebutuhan hidup dengan sumber air yang berkualitas tinggi.

Dalam era pembangunan dan perindustrian pada saat ini telah meningkatkan taraf hidup manusia, akan tetapi pembangunan menjadi suatu dampak pencemaran air yang sangat menyolok. Sungai-sungai dan sumber-sumber air 
banyak tercemar unsur kimia organik, non organik, logam berat, dan sebagainya yang dapat membawa kerugian fatal bagi tubuh manusia. Air yang tercemar bukan saja kehilangan daya detoksifikasinya untuk melancarkan metabolisme sel tubuh, tetapi juga merugikan tubuh kita

Timbulnya berbagai permasalahan diatas menjadikan jutaan masyarakat saat ini telah membelanjakan uangnya hanya untuk mendapatkan air bersih untuk diminum sehari-harinya. Secara singkat dapat dikatakan air memegang peranan penting dalam tubuh sehingga perlu diperhatikan kebersihan dan higienitasnya. Mengabaikan peranan penting air berarti anda menampung berbagai sumber penyakit dimasa akan datang. Persiapan dana yang besar untuk mengobatinya, hilangnya hari-hari bahagia bersama keluarga dan bahkan akibat paling buruk, anda kehilangan mata pencarian karena fisik tidak menunjang serta menjalani hidup lebih lama ditempat tidur karena sakit.

Gambaran ringkasan cerita diatas bukan merupakan rahasia umum lagi untuk saat ini. Hampir seluruh pelosok masyarakat mengetahui bahwa tubuh kita memerlukan air bersih yang sesuai dengan metabolisme sel tubuh.

Tetapi yang dihadapi masyarakat saat ini adalah sulitnya untuk mendapatkan air bersih dengan biaya murah dan dapat terjangkau.

Dengan adanya temuan baru beberapa tahun yang lalu tentang teknologi penyaringan air bersih (air isi ulang) dengan investasi yang cukup murah dan dapat dijadikan sebagai home industri (usaha mikro) dilokasi-lokasi permukiman. Harga jual produk otomatis sangat murah dibandingkan produk yang bermerek. Dan diperkirakan permintaan akan produk air isi ulang akan terus meningkat sejalan dengan perkembangan pengetahuan masyarakat tentang pentingnya air bersih untuk metabilosme sel-sel tubuh. Disamping itu pemerintah sangat mendukung dengan adanya usaha ini "Masyarakat dapat hidup sehat dengan biaya hidup ekonomi rendah".

\section{Rumusan Masalah}

Adapun dalam penelitian ini membahas permasalahan-permasalahan yang berkaitan dengan peramalan manajemen logistik, dan mencari solusi yang optimal guna menunjang kelancaran penyaluran dan penjualan dari Usaha Depot Air Minum Isi Ulang Al- Fitrah.

\section{Batasan Masalah}

Adapun batasan-batasan permasalahan yang akan dibahas yaitu sebagai berikut :

1. Penelitian ini tidak membahas masalah aspek biaya lebih mendalam/secara khusus.

2. Penelitian ini hanya terbatas pada masalah peramalan manajemen logistik dalam kaitannya dengan kebutuhan usaha depot air minum isi ulang Al- Fitrah untuk wilayah pemasaran kota Padang, Lubuk Buaya dan Lubuk Alung.

\section{Tujuan}

Berdasarkan rumusan, dan batasan masalah di atas dapat diketahui tujuan dari penelitian ini, yaitu:

1. Mengetahui pengertian peramalan dan system mengelolanya.

2. Mengetahui aktivitas-aktivitas utama dalam peramalan. 
3. Mengetahui apa itu peramalan dan kinerjanya.

\section{TINJAUAN TEORI}

Peramalan adalah seni dan ilmu untuk memperkirakan kejadian dimasa depan. Hal ini dapat dilakukan dengan melibatkan pengambilan data masa lalu dan menempatkannya ke masa yang akan datang dengan suatu bentuk model sistematis. (Prasetya, Drs. Hery, dan Fitri Lukiastuti, S.E, M.M : 2009 : 43)

Metode peramalan dapat diklasifikasikan dalam dua kategori, yaitu:

\section{Metode Kualitatif}

Metode ini digunakan dimana tidak ada model matematik, biasanya dikarenakan data yang ada tidak cukup representatif untuk meramalkan masa yang akan datang (long term forecasting). Peramalan kualitatif menggunakan pertimbangan pendapatpendapat para pakar yang ahli atau experd di bidangnya. Adapun kelebihan dari metode ini adalah biaya yang dikeluarkan sangat murah (tanpa data) dan cepat diperoleh. Sementara kekurangannya yaitu bersifat subyektif sehingga seringkali dikatakan kurang ilmiah.

Salah satu pendekatan peramalan dalam metode ini adalah Teknik Delphi, dimana menggabungkan dan merata-ratakan pendapat para pakar dalam suatu forum yang dibentuk untuk memberikan estimasi suatu hasil permasalahan di masa yang akan datang. Misalnya: berapa estimasi pelanggan yang dapat diperoleh dengan realisasi teknologi $3 \mathrm{G}$.

\section{Metode Kuantitatif}

Penggunaan metode ini didasari ketersediaan data mentah disertai serangkaian kaidah matematis untuk meramalkan hasil di masa depan. Terdapat beberapa macam model peramalan yang tergolong metode kualitiatif, yaitu:

a) Model-model Regresi

Perluasan dari metode Regresi Linier dimalan meramalkan suatu variabel yang memiliki hubungan secra linier dengan variabel bebas yang diketahui atau diandalkan.

b) Model Ekonometrik

Menggunakan serangkaian persamaanpersamaan regresi dimana terdapat variabel-variabel tidak bebas yang menstimulasi segmen-segmen ekonomi seperti harga dan lainnya.

c) Model Time Series Analysis (Deret Waktu)

Memasang suatu garis trend yang representatif dengan data-data masa lalu (historis) berdasarkan kecenderungan datanya dan memproyeksikan data tersebut ke masa yang akan datang.

I. Prosedur Peramalan

Menurut horizon waktunya, terdapat tiga tipe peramalan, yaitu :

1. Peramalan jangka pendek yang memberikan hasil peramalan 1 tahun atau kurang

2. Peramalan jangka menengah untuk meramalkan keadaan satu hingga lima tahun mendatang

3. Peramalan jangka panjang digunakan untuk pengambilan keputusan mengenai perencanaan produk dan perencanaan pasar, pengeluaran biaya perusahaan, studi kelayakan pabrik, anggaran, purchase order, perencanaan tenaga kerja dan perencanaan kapasitas kerja, serta segala kegiatan pengambilan 


\section{Jurnal Edik Informatika}

Penelitian Bidang Komputer Sains dan Pendidikan Informatika V1.i1(5-14)

keputusan yang berhubungan dengan

kejadian lebih dari lima tahun mendatang.

Metode yang digunakan dalam peramalan ada dua, yakni :

1. Metode Kuantitatif

2. Metode Kualitatif (Teknologis)

Metode peramalan kualitatif antara lain adalah :
a. Metode Delphi
b. Riset Pasar
c. Analogi Historik
d. Konsensus Panel

Metode peramalan yang akan digunakan adalah metode kuantitatif. Metode kuantitatif dapat digolongkan menjadi dua teknik :

\section{Teknik Deret Berkala (Time Series)}

Metode ini memperlakukan sistem seperti kotak hitam dengan tidak adanya usaha untuk menemukan faktor yang berpengaruh pada perilaku sistem tersebut. Metode ini cocok untuk peramalan jangka pendek atau menengah. Metode yang sering dipakai dalam Teknik Deret Berkala :

a. Metode Smoothing

b. Metode Dekomposisi

Metode-metode yang termasuk metode smoothing adalah :

a. Metode Average (rataan) Terdiri dari Mean (Simple Average), Single Moving Average, Double Moving Average, Weighted Moving Average.

\section{Metode Rata-rata (Simple Average)}

Metode rata-rata secara sederhana menghitung rataan dari data yang tersedia (sejumlah T). Persamaan metode rata-rata yaitu : $X=\sum_{i=1}^{T} \frac{X_{i}}{T}=F_{T+1}$

\section{Single Moving Average}

Istilah moving average menggambarkan prosedur jika ada data baru, rata-rata baru dapat dihitung dan data yang lalu dihapus. Rata-rata baru tersebut akan digunakan untuk meramal. Persamaan tersebut akan digunakan untuk meramal. Persamaan single moving average adalah :

$$
F_{T+1}=X=\sum_{i=n}^{T+(n-1)} \frac{X_{i}}{T}
$$

\section{Double Moving Average}

Peramalan double moving average meliputi 3 aspek yaitu :

\section{II.Menggunakan Single Moving} Average pada waktu t

III.Terjadi penyesuaian antara Single Moving Average dengan Double Moving Average $\left(\mathrm{S}_{\mathrm{t}}-\mathrm{S}_{\mathrm{t}}{ }_{\mathrm{t}}\right)$ pada saat $\mathrm{t}$.

IV.Terjadi penyesuaian trend $\mathrm{t}-\mathrm{N}+1$.

Aspek ini dapat dilihat pada persamaan peramalan sebagai berikut :

$$
\begin{aligned}
& S_{t}^{\prime}=\sum_{i=t}^{t-N+1} \frac{X_{i}}{N} \\
& S^{\prime \prime}{ }_{t}=\sum_{i=t}^{t-N+1} \frac{S^{\prime}{ }_{t}}{N} \\
& a_{t}=S_{t}^{\prime}+\left(S_{t}^{\prime}-S^{\prime \prime}{ }_{t}\right)=2 S_{t}^{\prime}-S^{\prime \prime}{ }_{t} \\
& b_{t}=\frac{2}{N-1}\left(S^{\prime}{ }_{t}-S^{\prime \prime}{ }_{t}\right) \\
& F_{t+m}=a_{t}+b_{t} m
\end{aligned}
$$

\section{b. Metode Exponential Smoothing}

1. Single Exponential Smoothing

Persamaan Single Exponential Smoothing adalah 


\section{Jurnal Edik Informatika}

Penelitian Bidang Komputer Sains dan Pendidikan Informatika V1.i1(5-14)

$$
\begin{aligned}
& : F_{t+1}=\alpha \cdot X_{t}+(1-\alpha) F_{t} \text { Atau } \\
& F_{t+1}=F_{t}+\alpha\left(X_{t}-F_{t}\right) F_{t+1}=F_{t}+\alpha\left(e_{t}\right)
\end{aligned}
$$

Berdasarkan rumus di atas, peramalan Single Exponential Smoothing dihitung berdasarkan hasil peramalan ditambah kesalahan peramalan periode sebelumnya. Jadi, kesalahan peramalan sebelumnya digunakan untuk mengoreksi peramalan berikutnya.

\section{Double Exponential Smoothing :} Brown's One Parameter Linear

Linear Exponential Smoothing dapat dilakukan jika tersedia 3 data dan satu nilai $\alpha$. Proses perhitungannya mirip dengan Linear Moving Average dengan persamaan sebagai berikut :

$$
\begin{aligned}
& S_{t}^{\prime}=\alpha \cdot X_{t}+(1-\alpha) \cdot S_{t-1}^{\prime} \\
& S_{t}^{\prime \prime}=\alpha \cdot S_{t}^{\prime}+(1-\alpha) \cdot S^{\prime \prime}{ }_{t-1} \\
& \quad a_{t}=S_{t}^{\prime}+\left(S_{t}^{\prime}-S^{\prime \prime}{ }_{t}\right)=2 S_{t}^{\prime}-S^{\prime \prime}{ }_{t} \\
& b_{t}=\frac{\alpha}{1-\alpha}\left(S_{t}^{\prime}-S^{\prime \prime}{ }_{t}\right) \\
& F_{t+1}=a_{t}+b_{t} m
\end{aligned}
$$

\section{Double Exponential Smoothing :} Holt's Two Parameter

Metode Holt's mirip dengan metode Brown dengan perbedaan melakukan smoothing trend secara terpisah. Pemisahan ini menciptakan fleksibilitas dimana smoothing trend dapat dilakukan dengan parameter yang berbeda dengan parameter yang dipakai series asli. Persamaan Holt's adalah sebagai berikut :

$$
\begin{aligned}
& S_{t}=\alpha \cdot X_{t}+(1-\alpha)\left(S_{t-1}+b_{t-1}\right) \\
& b_{t}=\gamma\left(S_{t}-S_{t-1}\right)+(1-\gamma) b_{t-1} \\
& F_{t+m}=S_{t}+b_{b} m
\end{aligned}
$$

Proses inisialisasi Holt's membutuhkan dua nilai estimasi, pertama nilai $\mathrm{S}_{1}$ dan berikutnya nilai trend $\mathrm{b}_{1}$.

\section{Triple Exponential Smoothing : Brown's} One Parameter Quadratic

Persamaan smoothing kuadratis adalah :

$$
\begin{aligned}
& S_{t}^{\prime}=\alpha \cdot X_{t}+(1-\alpha) S_{t-1}^{\prime} \\
& S_{t}^{\prime \prime}=\alpha \cdot S_{t}^{\prime}+(1-\alpha) S^{\prime \prime}{ }_{t-1} \\
& S^{\prime \prime}{ }_{t}=\alpha \cdot S^{\prime \prime}+(1-\alpha) S^{\prime \prime}{ }_{t-1} \\
& a_{t}=3 S_{t}^{\prime}-3 S^{\prime \prime}{ }_{t}+S^{\prime \prime}{ }_{t} \\
& b_{t}=\frac{\alpha^{2}}{2(1-a)^{2}}\left[(6-5 \alpha) S_{t}^{\prime}-(10-8 \alpha) S^{\prime \prime}{ }_{t}+(4-3 \alpha) S^{\prime \prime}{ }_{t}\right. \\
& c_{t}=\frac{\alpha^{2}}{(1-a)^{2}}\left(S^{\prime \prime}{ }_{t}-2 S^{\prime \prime}{ }_{t}+S^{\prime \prime}{ }_{t}\right) \\
& F_{t+m}=a_{t}+b_{t} m+\frac{1}{2} c_{t} m^{2}
\end{aligned}
$$

5. Triple Exponential Smoothing : Winter's Three ParameterTrend and Seasonality

Metode Winter's dapat digunakan untuk data musiman. Metode Winter's didasarkan 3 persamaan smoothing: satu untuk kestasioneran, satu untuk trend dan satu untuk musiman. Persamaan Winter's adalah :

$$
\begin{aligned}
& S_{t}=\alpha \frac{X_{t}}{I_{t-1}}+(1-\alpha)\left(S_{t-1}+b_{t-1}\right) \\
& b_{t}=\gamma\left(S_{t}-S_{t-1}\right)+(1-\gamma) b_{t-1} \\
& F_{t+m}=\left(S_{t}+b_{t} m\right) I_{t-1+m} \\
& I_{t}=\beta \frac{X_{t}}{S_{t}}+(1-\beta) I_{t-1}
\end{aligned}
$$

\section{PENGUMPULAN DAN PENGOLAHAN DATA}

\section{Pengumpulan Data}




\section{Jurnal Edik Informatika}

Penelitian Bidang Komputer Sains dan Pendidikan Informatika V1.i1(5-14)

I. Jenis Produk yang di Pasarkan : Air Minum Isi Ulang (galon)

II. Cakupan Pemasaran meliputi : Padang, yaitu daerah Lubuk Buaya dan Lubuk Alung (rumahan dan rumah makan)

Jumlah permintaan terhadap produk

a. Sasaran pembeli/konsumen : 550

Orang/hari

b. Jumlah Konsumen $\quad: 3.850$ Orang

c. Jumlah Persediaan : : 1000 galon /

hari

d. Total Persedian pertahun $: 365.000$ galon/ tahun

III. Proyeksi penjualan selama 1 tahun.

Tabel 3.1 Proyeksi penjualan tahun 2013

\begin{tabular}{|c|c|}
\hline Bulan & $\begin{array}{c}\text { Penjualan (demand) air minum } \\
\text { isi ulang Al- Fitrah/galon }\end{array}$ \\
\hline Januari & 16510 \\
\hline Februari & 16500 \\
\hline Maret & 15840 \\
\hline April & 16500 \\
\hline Mei & 16800 \\
\hline Juni & 16650 \\
\hline Juli & 16730 \\
\hline Agustus & 17028 \\
\hline September & 16450 \\
\hline Oktober & 15032 \\
\hline November & 15870 \\
\hline Desember & 15980 \\
\hline
\end{tabular}

Sumber : Depot Air minum isi Ulang Al- Fitrah

\section{Metode Moving Average}

Data Input Metode Moving Average

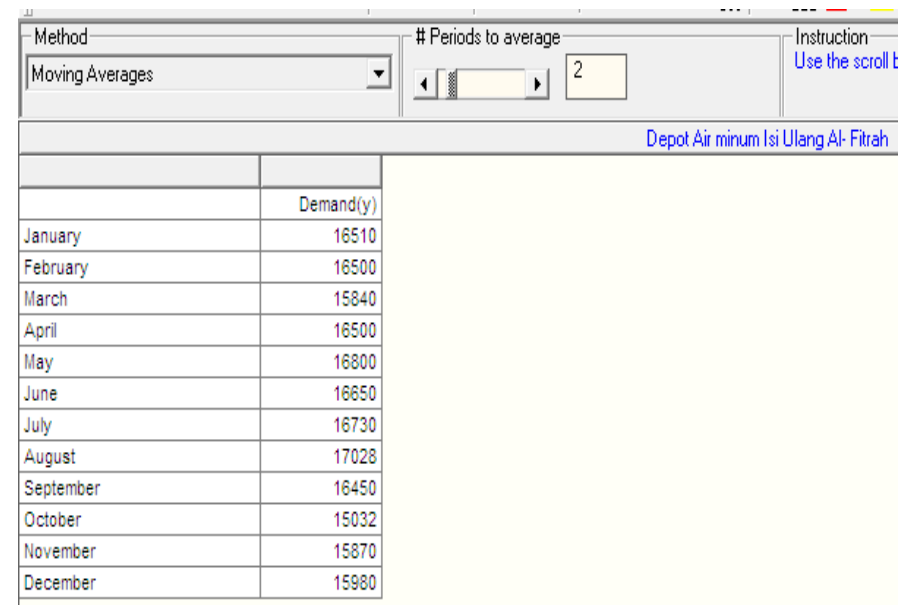

Gambar 3.1 Data Input Metode Average

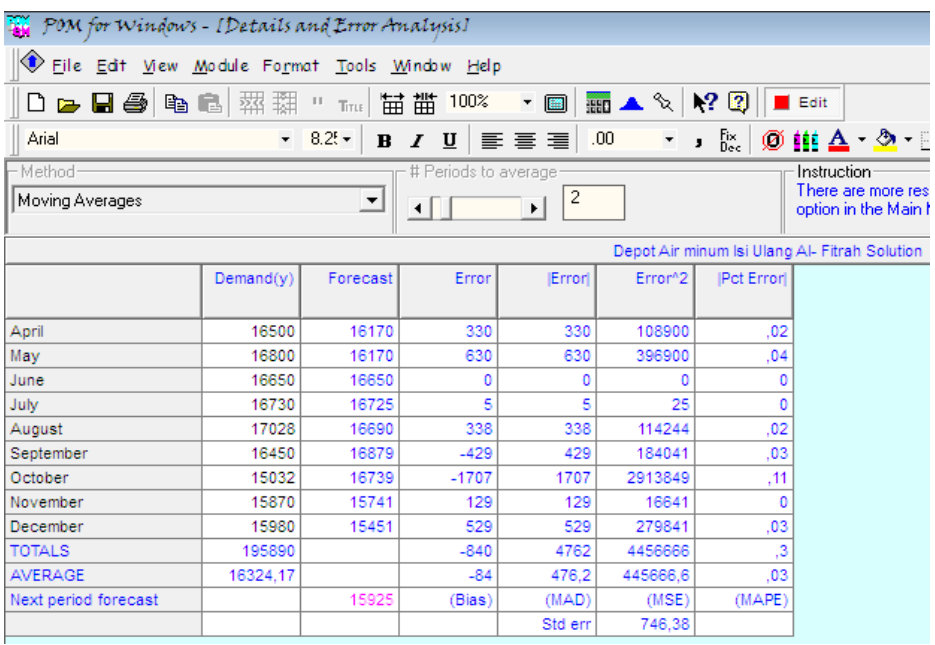

Gambar 3.2Data Output Metode Average

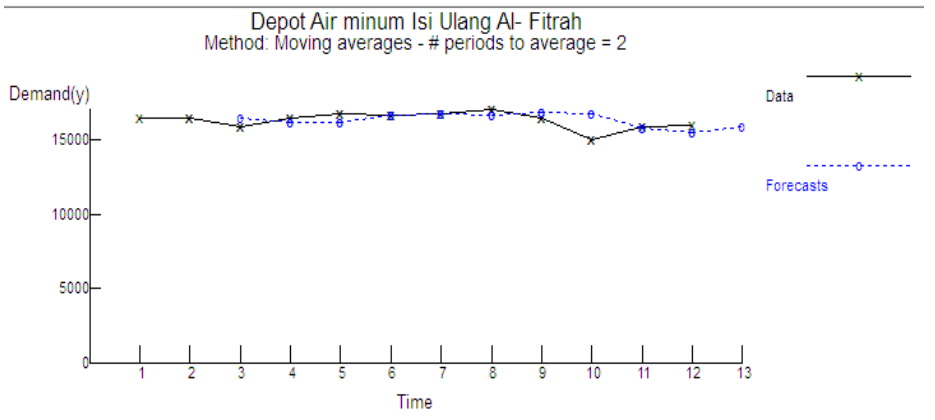

Gambar 3.3 Graph Metode Moving Average 


\section{Jurnal Edik Informatika}

E-ISSN : 2541-3716

Penelitian Bidang Komputer Sains dan Pendidikan Informatika V1.i1(5-14)

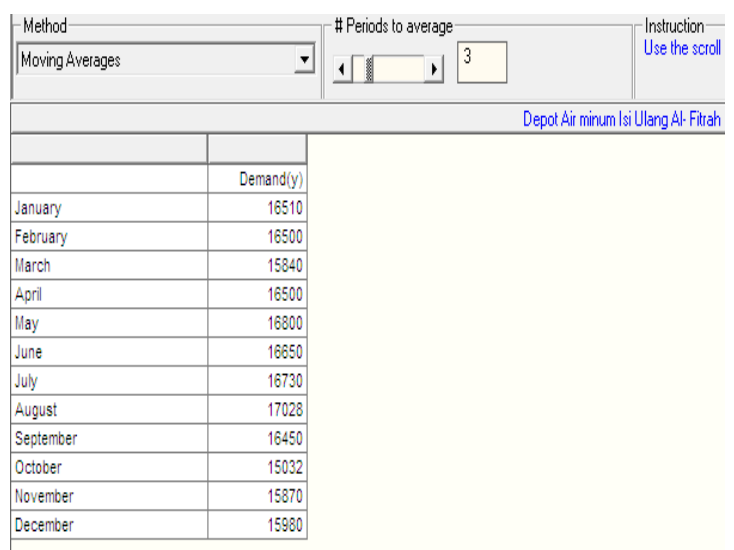

Gambar 3.4 Data Input Double Average

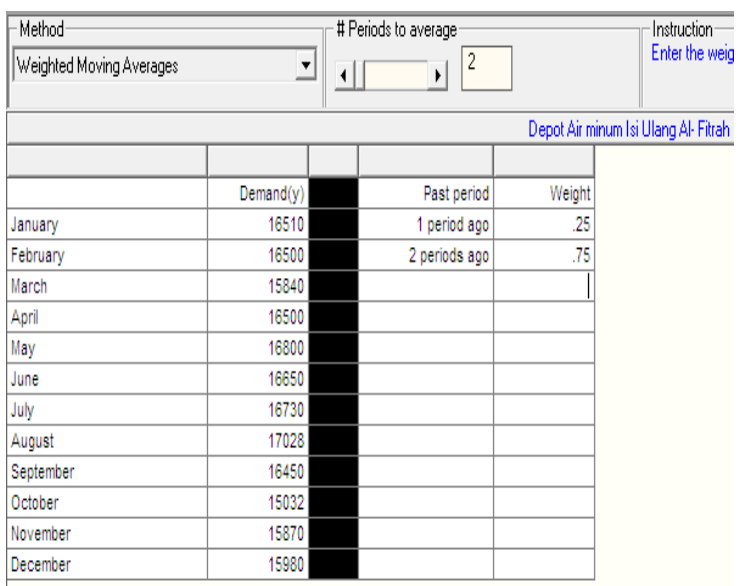

Gambar 3.7 Data Input WMA

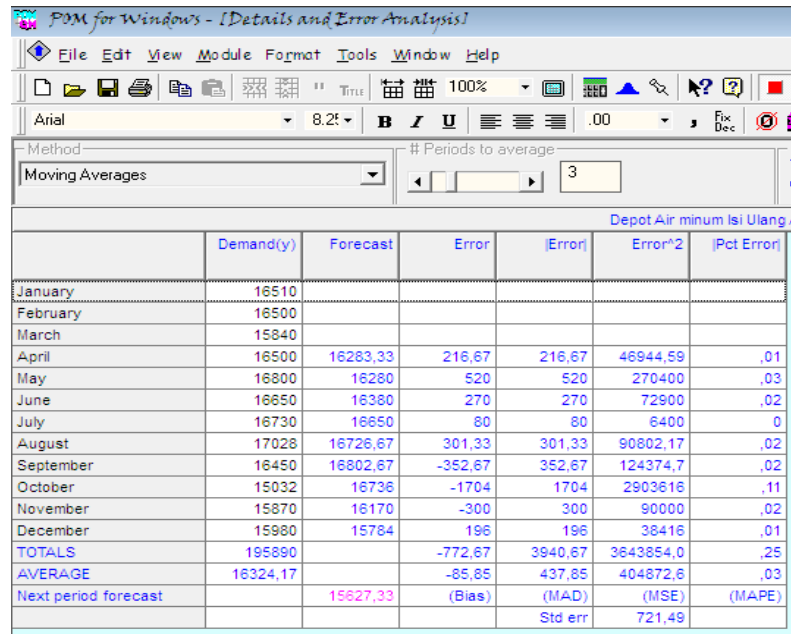

Gambar 3.5Data Output Double Average

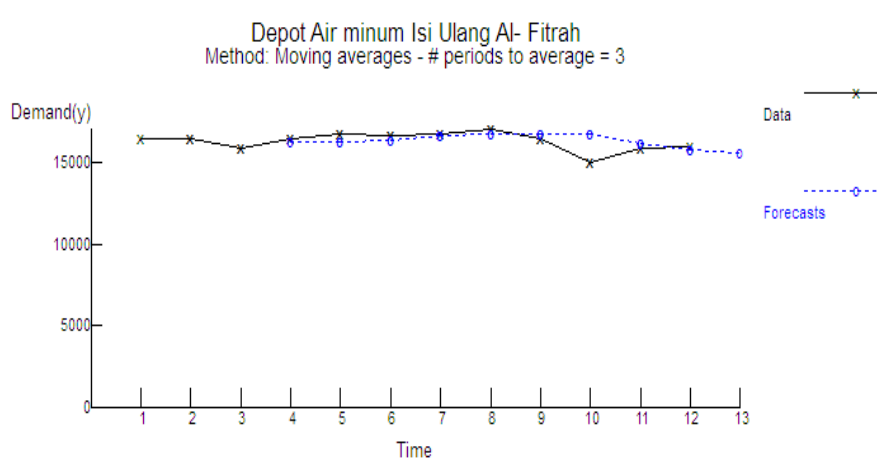

Gambar 3.6 Graph Double Average There are mor
option in the
(1) PoM for Windiows - IDetritsand Error Annalysist

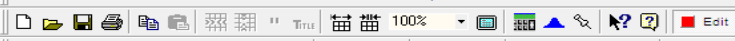

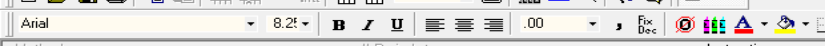
\begin{tabular}{l|l|l|l|l|l|l|l|l|l|l} 
Instructiotion \\
There are more res \\
option in the Main
\end{tabular}

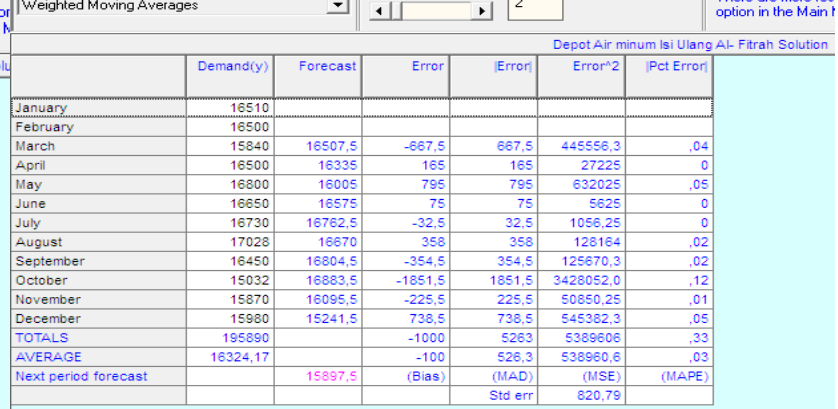

Gambar 3.8 Data Output WMA

DepotAir minum Isi Ulang Al- Fitrah

Method: Weighted Moving Averages - \#Periods to average: 2

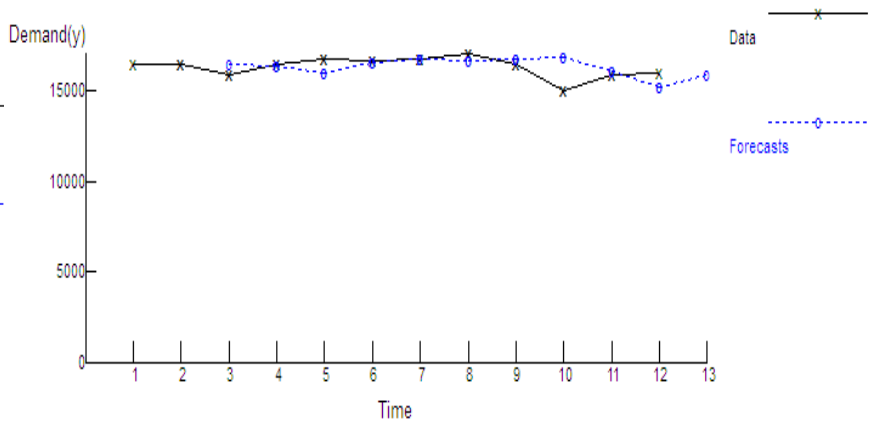

Gambar 3.9 Graph WMA 


\section{Jurnal Edik Informatika}

ISSN : 2407-0491

E-ISSN : 2541-3716

Penelitian Bidang Komputer Sains dan Pendidikan Informatika V1.i1(5-14)

\begin{tabular}{|c|c|c|c|c|}
\hline \multicolumn{2}{|l|}{ - Method- } & \multicolumn{2}{|c|}{-Alpha for smoothing- } & \multirow{2}{*}{$\begin{array}{l}\text { Instruction } \\
\text { Use the scroll } \\
\text { to find the valu }\end{array}$} \\
\hline Exponential Smoothing & $\square$ & 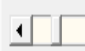 & 1) 0.25 & \\
\hline \multicolumn{5}{|c|}{ Depot Air minum Isi Ulang \&l. Fitrah } \\
\hline & & & & \\
\hline & Demand(y) & Forecas & & \\
\hline January & 16510 & 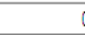 & & \\
\hline February & 16500 & c & & \\
\hline March & 15840 & c & & \\
\hline April & 16500 & c & & \\
\hline May & 16800 & c & & \\
\hline June & 16650 & c & & \\
\hline July & 16730 & 0 & & \\
\hline August & 17028 & c & & \\
\hline September & 16450 & c & & \\
\hline October & 15032 & c & & \\
\hline November & 15870 & 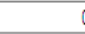 & & \\
\hline December & 15980 & c & & \\
\hline
\end{tabular}

Gambar 3.10 Data Input Exponential Smoothing
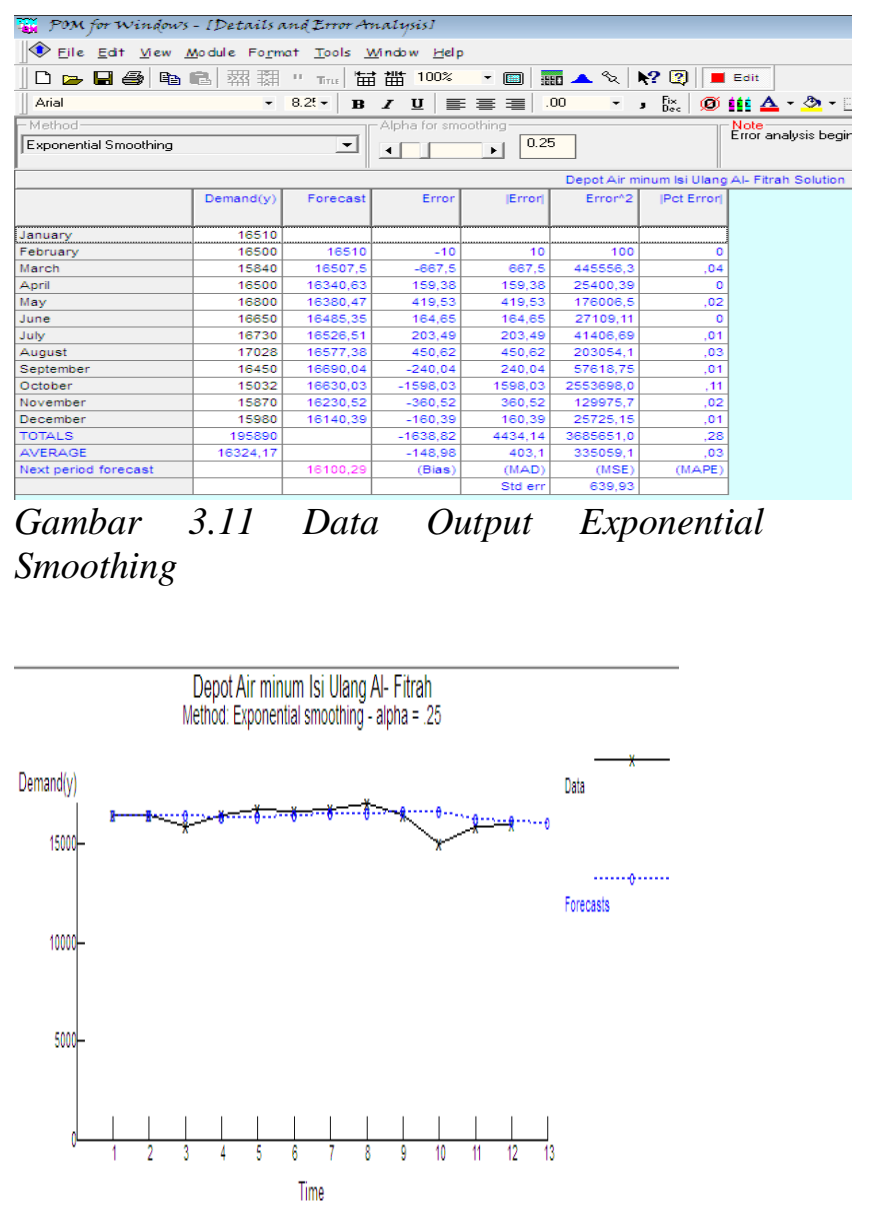

\section{Gambar 3.12 Graph \\ Exponential Smoothing}

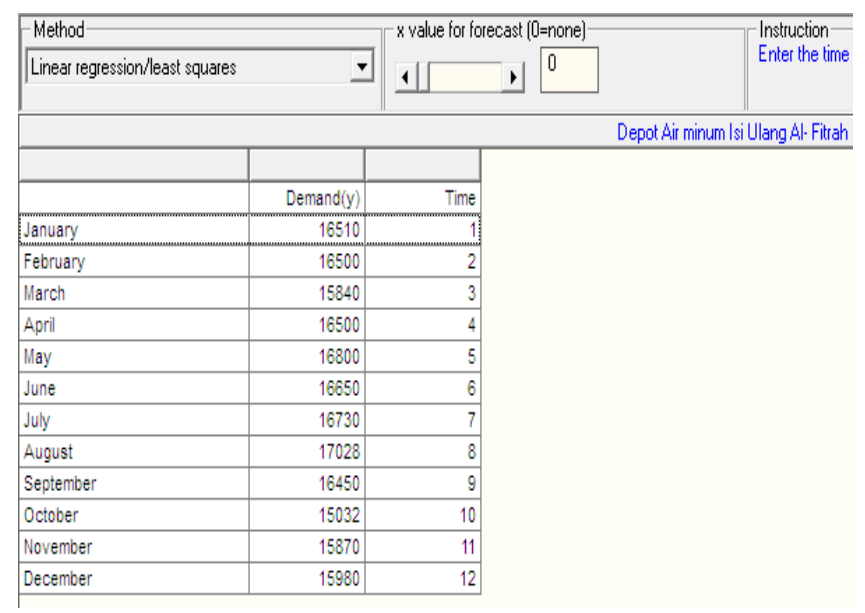

\section{Gambar 4.13 Data Input Linear Regretion}

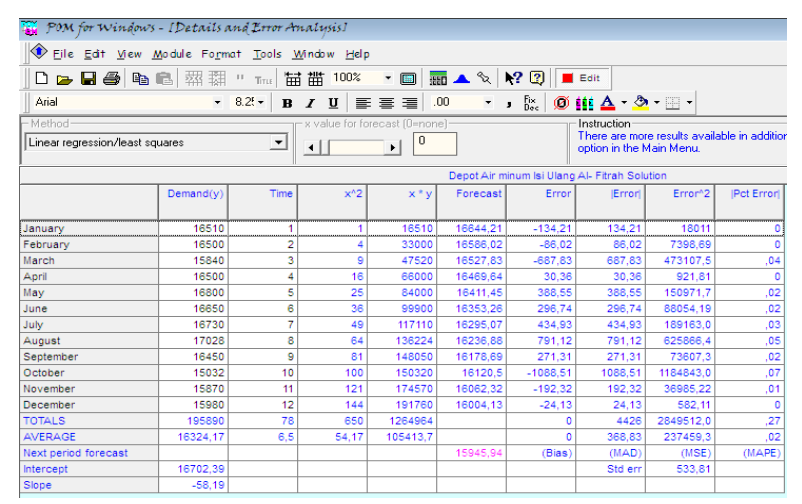

Gambar 4.14 Data Output Linear Regretion

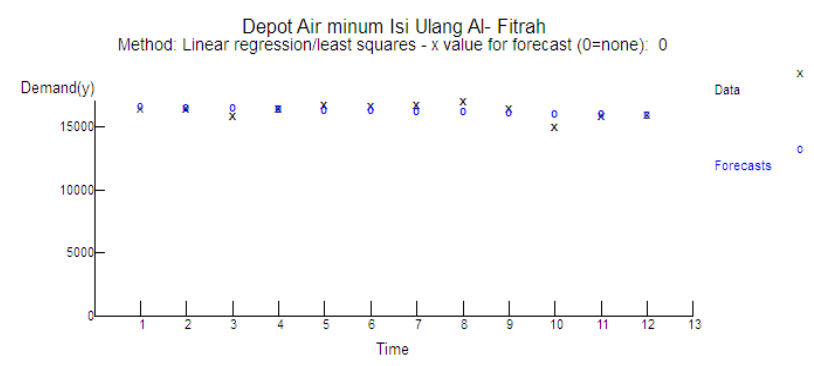

Gambar 4.15Graph Linear Regretion

\section{ANALISA HASIL}




\section{Jurnal Edik Informatika}

Penelitian Bidang Komputer Sains dan Pendidikan Informatika V1.i1(5-14)

Tabel 4.1 Peramalan Penjualan Untuk 12 Bulan Berikutnya

\begin{tabular}{|r|c|r|r|l|}
\hline $\mathbf{t}$ & $\mathbf{d}_{\mathbf{t}}$ & \multicolumn{1}{c|}{$\mathbf{t . d}_{\mathbf{t}}$} & \multicolumn{1}{c|}{$\mathbf{t}^{\mathbf{2}}$} & Forecast \\
\hline 1 & 16510 & 16510 & 1 & 16324,17 \\
\hline 2 & 16500 & 33000 & 4 & 16324,17 \\
\hline 3 & 15840 & 47520 & 9 & 16324,17 \\
\hline 4 & 16500 & 66000 & 16 & 16324,17 \\
\hline 5 & 16800 & 84000 & 25 & 16324,17 \\
\hline 6 & 16650 & 99900 & 36 & 16324,17 \\
\hline 7 & 16730 & 117110 & 49 & 16324,17 \\
\hline 8 & 17028 & 136224 & 64 & 16324,17 \\
\hline 9 & 16450 & 148050 & 81 & 16324,17 \\
\hline & & & & \\
\hline 1 & 15032 & 150320 & 100 & 16324,17 \\
\hline 0 & 150 & & & \\
1 & 15870 & 174570 & 121 & 16324,17 \\
\hline 1 & 15980 & 191760 & 144 & 16324,17 \\
\hline 2 & & & & jumlah \\
\hline 7 & 195890 & 1264964 & 650 \\
\hline
\end{tabular}

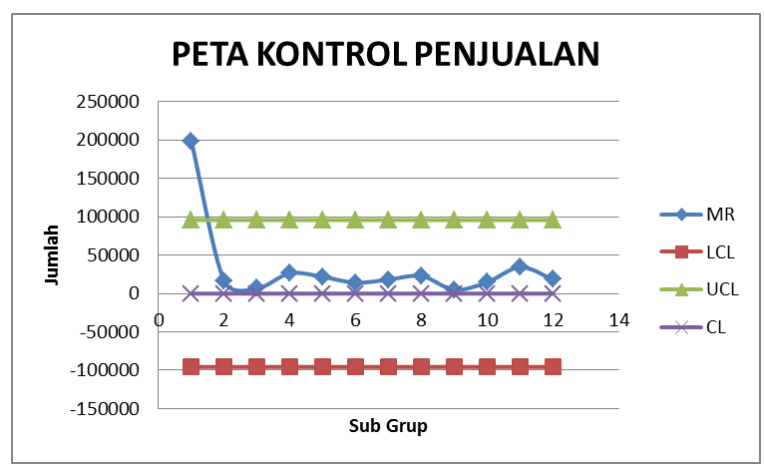

Gambar 4.1 Peta Kontrol Penjualan

\section{SIMPULAN}

1. Peramalan (forecasting) merupakan bagian vital bagi setiap organisasi bisnis dan untuk setiap pengambilan keputusan manajemen yang sangat signifikan.

2. Metode yang terdapat dalam peramalan yaitu: MA (Moving Average), Moving

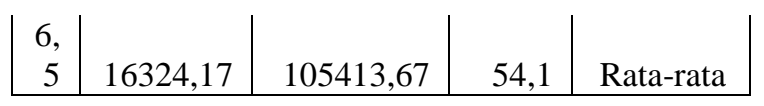

Tabel 4.2 Control Penjualan
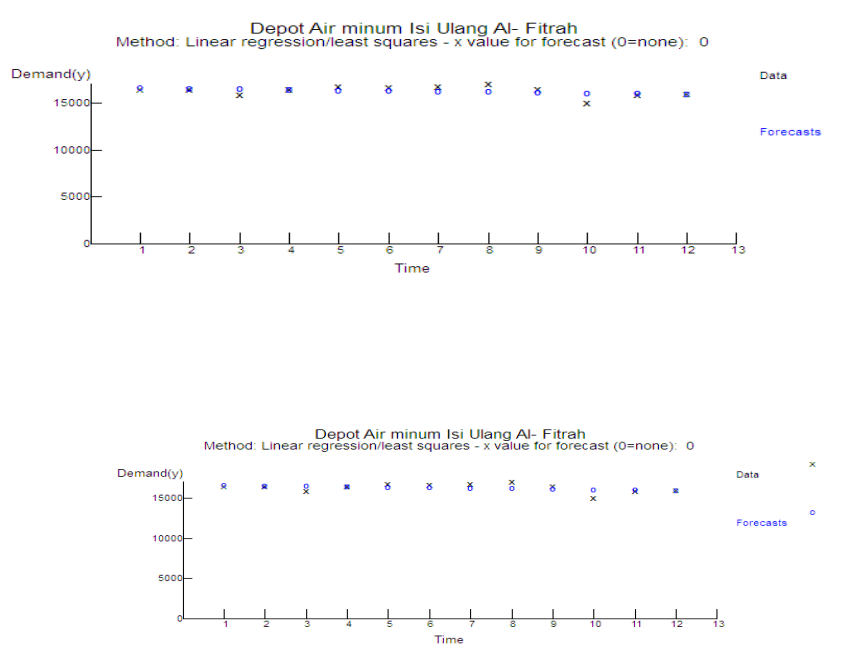

Double Average, Weighted Moving Average, Exponensial Smoothing, Linear regretion.

3. Dari ke lima metode diatas yang paling terbaik adalah metode Linear regretion karena memiliki persentase yang lebih kecil yaitu $0.02 \%$.

\section{SARAN}

Data yang akan di olah harus sesuai dengan data yang ada dalam suatu perusahaan ,agar didalam pengolahannya tidak ada hambatan yang terjadi.

\section{DAFTAR PUSTAKA}

Antarikso, Tjoko.1994. Manajemen Produksi. Jakarta: Erlangga

13 Diterbitkan Oleh Program Studi Pendidikan Informatika STKIP PGRI Sumbar 


\section{Jurnal Edik Informatika}

E-ISSN : 2541-3716

Penelitian Bidang Komputer Sains dan Pendidikan Informatika V1.i1(5-14)

Assauri, S. 1984. Teknik dan Metode Peramalan Penerapannya Dalam Ekonomi dan Dunia Usaha. Jakarta: Lembaga Penerbit Fakultas Ekonomi UI

Makridakis. 1993. Metode dan Aplikasi Peramalan. Jakarta: Bina Aksara

Subagyo, Pangestu. 1986. Forecasting Konsep dan Aplikasi. Yogyakarta: BPFE 